\title{
28 Research Square \\ The added value of transition programs in Dutch diabetes care: A controlled evaluation study
}

Research article

Keywords:

Posted Date: October 23rd, 2020

DOl: https://doi.org/10.21203/rs.3.rs-74456/v2

License: (c) (i) This work is licensed under a Creative Commons Attribution 4.0 International License.

Read Full License

Version of Record: A version of this preprint was published at Journal of Pediatric Nursing on August 1st, 2021. See the published version at https://doi.org/10.1016/j.pedn.2021.08.004. 


\section{Abstract}

The authors have requested that this preprint be withdrawn due to erroneous posting.

\section{Full Text}

The authors have withdrawn this preprint from Research Square. 